\title{
First records of emerging benthic invertebrates at a sublittoral soft-bottom habitat in northern Chile
}

\author{
Primeros registros de invertebrados bentónicos emergentes en un hábitat \\ sublitoral de fondos blandos en el norte de Chile
}

\author{
Aldo S. Pacheco ${ }^{1}$, Gonzalo E. Goméz ${ }^{2}$ and José M. Riascos ${ }^{1}$ \\ ${ }^{1}$ Instituto de Investigaciones Oceanológicas, Climate Change Ecology Group, CENSOR Laboratory, Universidad de Antofagasta, \\ Av. Jaime Guzmán 02800, P.O. Box 170, Antofagasta, Chile. babuchapv@yahoo.com \\ ${ }^{2}$ CENSOR Laboratory, Universidad de Antofagasta, Av. Jaime Guzmán 02800, Antofagasta, Chile
}

\begin{abstract}
Some benthic invertebrates perform vertical diel migrations by swimming up from the seabed to the water column, i.e., they emerge. Although such migrations may have important implications for benthic-pelagic coupling, there is no information reporting this type of ecological processes in sublittoral soft-bottom sediments in the Humboldt Current system. Herein, we present the results of a short-term experiment using traps designed to collect emerging invertebrates in a sublittoral site in northern Chile. Seventeen taxa principally composed by peracarids, copepods and ostracods were identified. This report constitutes the first description of an emerging benthic assemblage in the Humboldt Current ecosystem.
\end{abstract}

Key words: Diel vertical migrations, benthic-pelagic coupling, macrofauna

\section{INTRODUCTION}

Emerging benthos, also known as demersal zooplankton, are assemblages of meio- and macro-invertebrates that perform vertical migrations into the water column (Armonies 1988, Mess \& Jones 1997). At a diel scale these incursions into the water column occur from a position in/on the seabed during the day moving to the water column during the night and returning to the seabed during the day, although not all individuals of a population emerge in a given day/night. Incursions in water column by invertebrates are also mediated by bottom waters via resuspension and/or passive dispersion (Palmer 1988, Armonies 1994), however emerging assemblages are usually composed of active dispersers, which swim into the water column regardless of the intensity of bottom hydrodynamics (Teasdale et al. 2004). Emerging benthos play an important role in the benthic-pelagic coupling, i.e., some organisms feed on the water column and return to the seabed bringing water column resources to the benthos, and benthic organisms are consumed by pelagic predators moving benthic resources into the water column (Vallet \& Dauvin 2001).

From a biological point of view, multiple reasons have been proposed explaining these diel migrations including; reproduction (Hicks 1988, Thistle 2003), molting (Akiyama et al. 2004), predation and feeding (Alldredge \& King 1980; 1985) and post-larval dispersion (Ullberg \& Ólafsson
2003). Assemblages of emerging invertebrates have been documented in several benthic habitats ranging from vegetated and unvegetated soft- and hard- bottoms (Walters 1991, Walters \& Bell 1994, Jørgensen \& Christie 2003), tidal flats (Armonies 1994), sublittoral seafloor (Thistle 2003) and the deep sea (Thistle et al. 2007). However, these studies have mainly focused on ecological aspects of meiofaunal components particularly copepods (e.g., Walters 1991, Walters \& Bell 1994, Thistle 2003, Teasdale et al. 2004, Vopel \& Thistle 2011), thus for a better understanding of the ecological consequences of these migrations it is important to describe and to include macrofaunal components into the analysis of emergence processes.

To our knowledge, there is no information about emerging benthos in sublittoral soft-bottom habitats of the Humboldt Current ecosystem. This is surprising considering the growing interest to understand the functioning of this ecosystem in terms of energy and matter flow throughout benthic-pelagic coupling (e.g., Vargas et al. 2007). Colonization experiments using containers filled with defaunated sediments positioned between 5 and $27 \mathrm{~cm}$ above the seabed, suggested that active swimming was the main mechanism of post-larval colonization in shallow, sublittoral, soft-bottom habitats in northern Chile (Pacheco et al. 2010, 2012, 2013). 
However, it needs to be revealed if these colonizers where part of the emerging benthos. Therefore, the aim of this study was to describe the macrofaunal assemblage that performs diel vertical migrations (i.e., emerging benthos) for the first time, in a shallow sublittoral soft-bottom habitat in northern Chile.

\section{Materials AND MEthods}

An experiment was conducted in late April 2012 in Bolsico $\left(23^{\circ} 28^{\prime} \mathrm{S} ; 70^{\circ} 36^{\prime} \mathrm{W}\right)$ a small and sheltered cove at the southern part of Península Mejillones, Antofagasta Region. In this location, the soft-bottom habitat at $7.5 \mathrm{~m}$ depth is composed of poorly sorted sand and bottom current velocity is rather low $\left(\sim 2.7 \mathrm{~cm} \mathrm{~s}^{-1}\right.$, current meter placed $50 \mathrm{~cm}$ above the bottom). Details of the abiotic characteristics of the site are available in Pacheco et al. (2012). The experiment was conducted in a low-bottom current location in order to distinguish active emerging invertebrates from those that may be resuspended by strong hydrodynamics in a more exposed site. To study the emerging assemblage composition, invertebrates were captured using emergence traps (see design details in Fig. 1A) with 2 different designs. The first design, i.e., bottom traps, consisted of traps placed onto the sediment surface so that the outer rim of the inverted funnel (i.e., the base of the trap) was in contact with the sediment surface (Fig. 1B). In addition, since it has been suggested that emerging organisms may use bottom current cues to trigger migrations into the water column (Palmer 1988, Armonies 1994), the second design consisted of traps (i.e., leg traps) installed $3 \mathrm{~cm}$ above the sediment surface

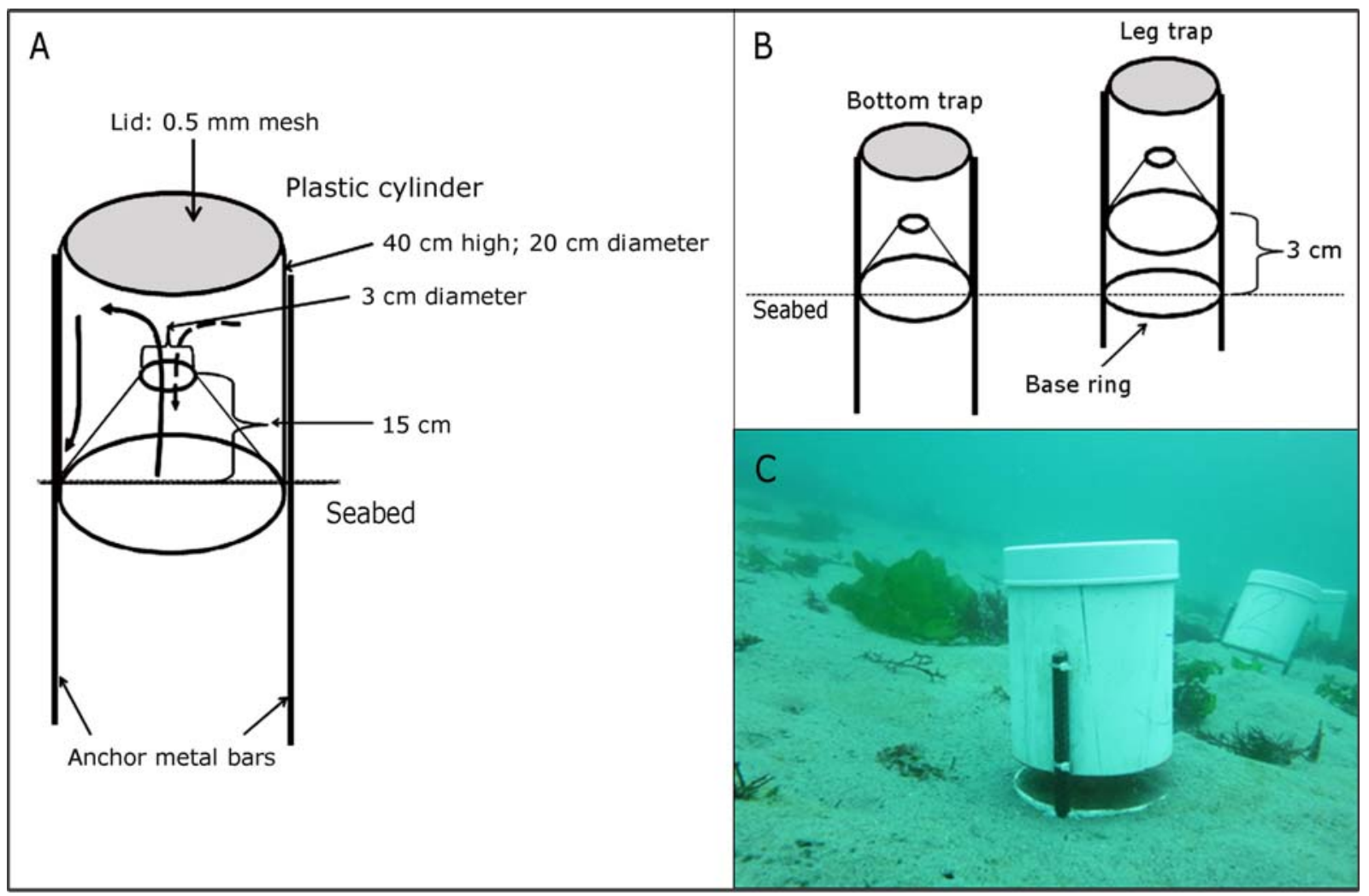

Figure 1. A) Emergence trap design; the collecting chamber consists of a plastic cylinder with an inverted funnel installed in the bottom part. The area covered by the trap base was $314.15 \mathrm{~cm}^{2}$ and the volume of the traps was 2.8 liters. Solid arrows represent the path taken by emerging organisms to be captured in the bottom of the trap. Some might scape throughout the opening (dotted arrow). B) Scheme of the both types traps used in the experiment. The base ring of the leg traps was $1 \mathrm{~cm}$ wide and it was inserted into the sediment, keeping a fix $3 \mathrm{~cm}$ distance between the sediment and the trap base border. C) View of the leg trap in situ / A) Diseño de la trampa de emergencia; la cámara colectora consiste en un cilindro plástico con un embudo invertido instalado en la parte basal. El área cubierta por la base es $314,15 \mathrm{~cm}^{2}$ y el volumen de la trampa es 2,8 litros. Las flechas solidas muestran la ruta que siguieron los organismos capturados en el fondo de la trampa. Existe la posibilidad de escape a través de la apertura (flechas punteadas). B) Esquema de los dos tipos de trampas usadas en el experimento. El ancho del anillo en la trampa de parantes es de $1 \mathrm{~cm}$ y fue insertado en el sedimento manteniendo una distancia fija de $3 \mathrm{~cm}$ entre la superficie del sedimento y la base de la trampa. C) Vista in situ de la trampa de parantes 


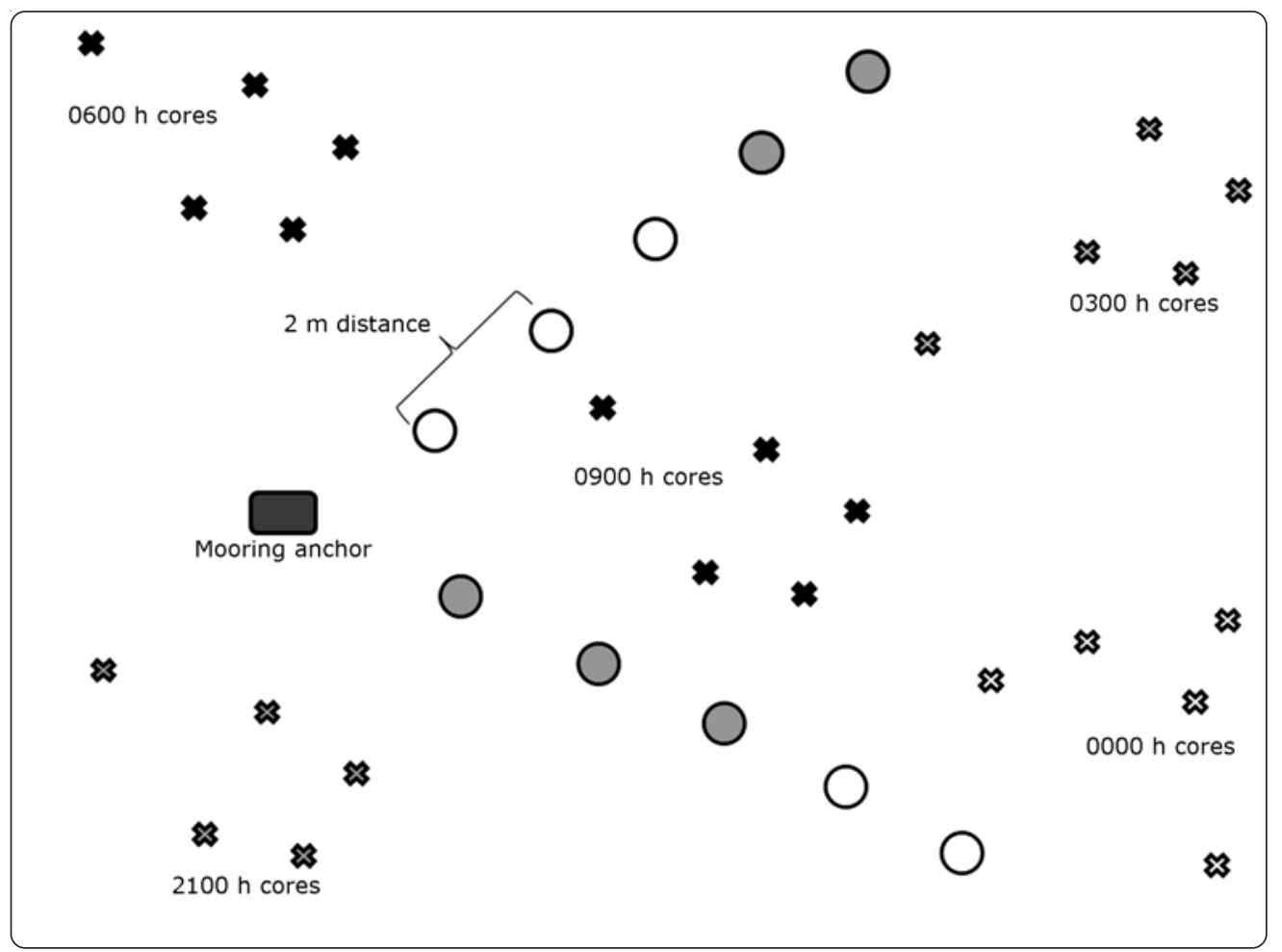

Figure 2. Schematic representation of the emerging traps deployment and position of the sediment cores during night/day sampling. Bottom traps (gray circles), leg traps (white circles) / Representación esquemática del arreglo de las trampas de emergencia y las posiciones de los cores durante los muestreos nocturno/ diurno. Trampas de fondo (círculos grises), trampas de parantes (círculos blancos)

thus allowing bottom water to flow (Fig. 1B). Similar distance between the trap base and sediment surface has proved to be successful collecting emerging invertebrates (e.g., Thistle et al. 2007). Five bottom and 5 leg traps were installed at $1800 \mathrm{~h}$ in the afternoon (i.e., half hour before dusk) and collected the next day at $0900 \mathrm{~h}$. Traps were installed in 2 rows in an ' $\mathrm{L}$ ' shape deployment and always keeping a distance of $2 \mathrm{~m}$ between traps (Fig. 2). The first row consisted in 3 leg and 2 bottom traps while the second row was made of 2 leg and 3 bottom traps. At the time of collection, traps were closed with rubber plugs inserted in the inner part of the funnel, and carefully transported onboard by divers. The collecting chambers of each trap were washed and the retained organisms were deposited in labeled plastic bags containing a $10 \%$ formalin solution with rose bengal for coloration. In the laboratory, samples were washed and sieved through a $0.5 \mathrm{~mm}$ mesh with a $0.3 \mathrm{~mm}$ mesh underneath, in order to retain very small organisms. Samples of both types were transferred into jars with
$90 \%$ alcohol for preservation. In addition, sediment samples were collected from the upper $5 \mathrm{~cm}$ of the sediment using a cylindrical core (10 cm diameter and $15 \mathrm{~cm}$ high). Every 3 hours, 5 sediment samples were randomly taken in areas $3 \mathrm{~m}$ apart of the traps deployment (Fig. 2). Onboard, the collected sediment was preserved in plastic bags with the formalin solution. In the laboratory, organisms were counted and identify to the lowest possible taxonomic level with the aid of micro- and stereoscopes. Traps and sediment sampling was repeated 3 times at one-week intervals.

To determine true emerging organisms, the following criteria was adopted: (a) organisms collected in the trap chamber from both bottom and leg designs and also present in the day sediment sample but not in the night sediment sample $=$ emerging organisms, (b) present in both traps and also in night and day sediment samples = emerging organisms, since not all organisms of the same population emerge, (c) present in the trap chamber in bottom and leg designs but not present in none of the 
Table 1. Mean ( $\pm S D$ ) abundance of invertebrates collected in traps and sediments at Bolsico. El: Emerging invertebrates. Taxonomic affiliation: (A) amphipod, ( $\mathrm{Cr}$ ) crustacean, (Co) copepod, (O) ostracod, (Ch) chaetognate, (G) gastropod, (B) bivalve, (T) tunicate, (P) polychaete, (ind.) indeterminate / Abundancia promedio $( \pm D E)$ de los invertebrados colectados en trampas y sedimentos de Bolsico. El: invertebrados emergentes. Afiliación taxonómica: $(\mathrm{A})$ anfípodo, $(\mathrm{Cr})$ crustáceo, $(\mathrm{Co})$ copépodo, $(\mathrm{O})$ ostrácodo, $(\mathrm{Ch})$ chaetognato, $(\mathrm{G})$ gastropodo, $(\mathrm{B})$ bivalvo, $(\mathrm{T})$ tunicado, $(\mathrm{P})$ poliqueto, (ind.) indeterminado

\begin{tabular}{|c|c|c|c|c|c|c|}
\hline & Family & Genus/species/stage & $\begin{array}{c}\text { Bottom trap } \\
n=15\end{array}$ & $\begin{array}{c}\text { Leg trap } \\
\mathrm{n}=15\end{array}$ & $\begin{array}{l}\text { Sediment day } \\
n=30\end{array}$ & $\begin{array}{c}\text { Sediment night } \\
\mathrm{n}=45\end{array}$ \\
\hline A & Aoridae & Aora typica EI & $1.9 \pm 2.6$ & $1.4 \pm 2.02$ & $0.03 \pm 0.1$ & - \\
\hline A & Platyischnopidae & Eudevenopus gracilipes EI & $10.8 \pm 15.7$ & $5.6 \pm 4.07$ & $62.1 \pm 37.4$ & $47.4 \pm 31.3$ \\
\hline A & Liljeborgidae & Liljeborgia sp. EI & $0.6 \pm 0.9$ & $0.3 \pm 0.7$ & $2.6 \pm 2.3$ & $1.5 \pm 1.4$ \\
\hline A & Phoxocephalidae & Heterophoxus sp. EI & $0.09 \pm 0.5$ & $0.2 \pm 0.6$ & $1.2 \pm 1.4$ & $1.5 \pm 1.7$ \\
\hline A & Phoxocephalidae & Microphoxus sp. EI & $0.4 \pm 0.7$ & $2.6 \pm 9.4$ & $34.7 \pm 12.5$ & $24.3 \pm 17.4$ \\
\hline A & Ampeliscidae & Ampelisca sp. EI & $0.2 \pm 0.1$ & - & $0.03 \pm 0.1$ & - \\
\hline $\mathrm{Cr}$ & Diastylidae & Diastilys planifrons EI & $3.2 \pm 5.4$ & - & $1.2 \pm 1.2$ & - \\
\hline $\mathrm{Cr}$ & Mysidacea & Mysis sp. EI & $20.6 \pm 21.5$ & $59.9 \pm 53.9$ & $12.5 \pm 10.3$ & - \\
\hline Co & Acartiidae & Acartia tonsa $\mathrm{EI}$ & $5.7 \pm 9.2$ & $62.1 \pm 12.2$ & $3.5 \pm 9.9$ & $0.1 \pm 0.3$ \\
\hline Co & Paracalanidae & Paracalamus sp. EI & $27.1 \pm 52.5$ & $80.1 \pm 19.6$ & $9.5 \pm 11.6$ & - \\
\hline Co & Corycaeidae & Corycaeus speciosus EI & $2.5 \pm 4.5$ & $11.6 \pm 22.6$ & $0.05 \pm 0.3$ & $0.08 \pm 0.3$ \\
\hline Co & Calanidae & Centropages brachiatus EI & $8.8 \pm 14.2$ & $7.3 \pm 13.3$ & $0.03 \pm 0.1$ & $0.2 \pm 0.1$ \\
\hline Co & Harpacticidae & Tigriopus sp. EI & $68.7 \pm 55.4$ & $37.8 \pm 28.6$ & $12.2 \pm 3.4$ & $10.3 \pm 7.9$ \\
\hline Co & Peltidiidae & Clytemnestra scutellata EI & $1.8 \pm 3.09$ & $0.7 \pm 1.3$ & $2.6 \pm 5.2$ & $0.9 \pm 1.7$ \\
\hline Co & Euterpinidae & Euterpina acutifrons EI & $0.6 \pm 1.3$ & $0.5 \pm 1.01$ & $0.6 \pm 1.2$ & $0.7 \pm 1.5$ \\
\hline Co & Centropagidae & Centropages brachiatus EI & $8.8 \pm 14.2$ & $7.3 \pm 13.3$ & $3.5 \pm 11.5$ & $0.7 \pm 7.3$ \\
\hline Co & Ectinosomatidae & Microsetella rosea EI & $0.3 \pm 2.1$ & $0.7 \pm 1.2$ & $5.5 \pm 10.6$ & $3.1 \pm 8.4$ \\
\hline Co & Ectinosomatidae & Microsetella norwegica EI & $0.3 \pm 1.09$ & $0.8 \pm 1.5$ & $9.5 \pm 19.6$ & $8.7 \pm 16.6$ \\
\hline $\mathrm{O}$ & Cylindroleberididae & Ostracod ind. EI & $1.6 \pm 1.6$ & $0.8 \pm 1.03$ & $47.5 \pm 40.5$ & $38.5 \pm 32.7$ \\
\hline $\mathrm{O}$ & Sarsiellidae & Ostracod ind. EI & $0.3 \pm 1.09$ & $0.8 \pm 1.5$ & $9.5 \pm 19.6$ & $8.7 \pm 16.6$ \\
\hline $\mathrm{Cr}$ & Decapoda & Zoea ind. EI & $0.5 \pm 1.09$ & - & $4.1 \pm 4.1$ & - \\
\hline A & Dexaminidae & Indeterminate EI & $0.1 \pm 0.5$ & $0.1 \pm 0.4$ & $0.2 \pm 0.4$ & - \\
\hline $\mathrm{Cr}$ & Callianassidae & Callianasid ind. EI & $0.3 \pm 3.2$ & $0.2 \pm 0.4$ & $0.05 \pm 0.2$ & - \\
\hline $\mathrm{P}$ & Indeterminate & Polychaeta post-larvae EI & $0.5 \pm 2.3$ & $0.1 \pm 0.5$ & $0.8 \pm 2.2$ & $0.7 \pm 1.4$ \\
\hline $\mathrm{Ch}$ & Sagittidae & Sagitta sp. & - & $0.01 \pm 0.1$ & $0.01 \pm 0.1$ & - \\
\hline A & Nebaliopsidae & Indeterminate & - & - & $0.04 \pm 0.2$ & - \\
\hline $\mathrm{Cr}$ & Caprellidae & Caprella sp. & - & $0.03 \pm 0.1$ & - & - \\
\hline $\mathrm{Cr}$ & Luciferidae & Lucifer $\mathrm{sp}$. & - & $0.07 \pm 0.3$ & - & - \\
\hline A & Ischyroceridae & Jassa sp. & - & $0.01 \pm 0.1$ & - & - \\
\hline $\mathrm{Cn}$ & Sagartiidae & Anthothoe chilensis & - & - & $0.03 \pm 0.16$ & - \\
\hline $\mathrm{T}$ & Oikopleuridae & Oikopleura sp. & $5.4 \pm 10.7$ & $8.6 \pm 10.7$ & - & - \\
\hline G & Caecidae & Caecum chilensis & $0.01 \pm 0.1$ & - & $0.7 \pm 1.7$ & $0.8 \pm 1.4$ \\
\hline G & Nassariidae & Nassarius gayi & $0.9 \pm 1.8$ & $0.6 \pm 1.5$ & $0.5 \pm 1.06$ & $0.3 \pm 0.7$ \\
\hline G & Caecidae & Fartulum sp. & - & $0.01 \pm 0.1$ & $0.1 \pm 1.5$ & $0.2 \pm 0.7$ \\
\hline B & Nuculinae & Linucula pisum & $0.03 \pm 1.8$ & $0.03 \pm 0.1$ & $2.03 \pm 2.02$ & $2.0 \pm 2.2$ \\
\hline B & Solecurtidae & Tagelus dombeii & - & - & $2.1 \pm 2.4$ & $1.2 \pm 1.3$ \\
\hline B & Psammobiidae & Gari solida & - & - & $6.6 \pm 6.9$ & $8.1 \pm 7.7$ \\
\hline B & Veneridae & Protothaca thaca & - & - & $4.7 \pm 7.7$ & $2.1 \pm 3.6$ \\
\hline $\mathrm{Cn}$ & Indeterminate & Hydromedusas ind. & $0.4 \pm 1.4$ & $1.5 \pm 5.2$ & - & - \\
\hline $\mathrm{Cr}$ & Indeterminate & Isopod ind. & $0.04 \pm 0.2$ & $0.01 \pm 0.1$ & - & - \\
\hline Co & Calanidae & Calamus chilensis & $0.3 \pm 0.9$ & $2.3 \pm 7.2$ & - & - \\
\hline Co & Oncaeidae & Oncaea sp. & $0.5 \pm 1.8$ & $0.1 \pm 0.6$ & - & - \\
\hline Co & Eucalanidae & Eucalamus sp. & $0.1 \pm 1.4$ & $0.05 \pm 0.2$ & - & - \\
\hline Co & Oithonidae & Oithona similis & $0.9 \pm 3.2$ & $0.4 \pm 1.3$ & - & - \\
\hline Co & Oithonidae & Oithona plumifera & - & $0.6 \pm 1.6$ & - & - \\
\hline $\mathrm{Cr}$ & Indeterminate & Cladocera ind. & - & $0.01 \pm 0.01$ & - & - \\
\hline $\mathrm{Cr}$ & Euphausiidae & Euphausid ind. & - & $0.01 \pm 0.01$ & - & - \\
\hline B & Indeterminate & Bivalve post-larvae & - & $0.2 \pm 1.22$ & $16.3 \pm 20.9$ & $12.5 \pm 13.5$ \\
\hline B & Indeterminate & Bivalve ind. & - & - & $0.8 \pm 5.3$ & $1.9 \pm 6.7$ \\
\hline G & Indeterminate & Gastropods post-larvae & $0.06 \pm 0.3$ & - & - & - \\
\hline$P$ & Pisionidae & Indeterminate & - & - & - & $0.02 \pm 0.1$ \\
\hline $\mathrm{P}$ & Spionidae & Indeterminate & - & - & $5.5 \pm 4.1$ & $5.3 \pm 5.3$ \\
\hline$P$ & Spionidae & Spiophanes bombix & - & - & $3.6 \pm 5.1$ & $3.3 \pm 3.4$ \\
\hline $\mathrm{P}$ & Polynoidae & Indeterminate & $0.04 \pm 0.2$ & - & $0.3 \pm 0.5$ & $0.6 \pm 1.3$ \\
\hline $\mathrm{P}$ & Cirratulidae & Indeterminate & - & - & $0.1 \pm 0.5$ & $0.4 \pm 0.8$ \\
\hline $\mathrm{P}$ & Capitellidae & Indeterminate & - & - & $0.9 \pm 2.04$ & $0.8 \pm 1.3$ \\
\hline $\mathrm{P}$ & Lumbrineridae & Indeterminate & - & - & $0.3 \pm 1.9$ & $0.1 \pm 0.7$ \\
\hline $\mathrm{P}$ & Maldanidae & Indeterminate & - & - & $0.9 \pm 2.04$ & $0.8 \pm 1.3$ \\
\hline$P$ & Hesionidae & Indeterminate & - & - & $0.1 \pm 0.8$ & $0.1 \pm 0.4$ \\
\hline$P$ & Orbiniidae & Haploscoloplos chilensis & - & - & $0.2 \pm 0.9$ & $0.1 \pm 0.6$ \\
\hline$P$ & Goniadidae & Indeterminate & - & - & $0.05 \pm 0.2$ & $0.1 \pm 0.3$ \\
\hline $\mathrm{P}$ & Opheliidae & Indeterminate & - & - & $0.03 \pm 0.1$ & - \\
\hline $\mathrm{P}$ & Arenicolidae & Indeterminate & - & - & $0.2 \pm 0.5$ & $0.2 \pm 0.6$ \\
\hline
\end{tabular}


sediment samples = no emerging organisms, likely pelagic, and (d) present in the leg trap but not in bottom trap and not present in sediment samples $=$ no emerging organisms, likely pelagic entering throughout the elevated part of the trap.

\section{Results AND DISCUSSION}

A total of 63 taxa were recorded during this experiment, 53 were recorded in sediment samples and a total of 38 from both trap types (Table 1). Using the criteria mentioned above, the results of this experiment indicate that the emergence assemblage was composed of 24 species constituting the $38 \%$ of the total taxa recorded. The emerging assemblage was composed principally by crustaceans, consisting of 7 amphipods, one cumacean, one mysid, one callianasid, one brachyuran zoea, 10 copepods, 2 ostracods, and one polychaete post-larva (Table 1). The taxonomic composition of this assemblage is similar to that reported in most of the studies dealing with emerging benthos in which crustaceans are one of the most common taxa reported. For example, copepods, polychaetes, amphipods, isopods, mysids, cumaceans and tanaids constituted the emerging assemblage of experimental studies (e.g., Alldredge \& King 1980, 1985). Adult polychaetes, isopods, and tanaids have been also reported and even though these were identified in the samples, none of them meet the criteria used for the assignation of emerging benthos. Other studies have studied principally harpacticoids copepods (e.g., Thistle 2003, Teasdale et al. 2004, Vopel \& Thistle 2011). We recorded the following harpacticoid copepods; Tigriopus sp., Euterpina acutifrons, Clytemnestra scutellata, Microsetella rosea, and $M$. norwegica thus concurring with the aforementioned studies. However, it is worth noting that we conducted a short-term experiment and likely the taxonomic richness of the assemblage may increase by enhancing the temporal and spatial replication of these experiments.

Studies on ecological aspects of the emerging benthos have been conducted focusing on single groups, such as the case of nematodes (e.g., Ullberg \& Ólafsson 2003) and copepods (e.g., Thistle 2003). Harpacticoid copepods in particular, have been subject of several studies at different sublittoral habitats (Thistle 2003, Teasdale et al. 2004, Vopel \& Thistle 2011) and the deep sea (Thistle et al. 2007). In agreement to that evidence, 4 harpacticoid species were present in our traps thus providing further evidence of the widespread distribution of this emerging component in soft-bottom communities. It is also worth mentioning the presence of the calanoids Acartia tonsa and Paracalanus sp., as part of the emerging benthos assemblage. These 2 species are abundant components of the zooplankton linking the primary production with upper trophic levels in the pelagic habitat of this upwelling system (Vargas \& Gonzalez 2004). Their presence as part of the emerging benthos suggests that this species might be involved in the transference of the primary production in the water column to the benthic habitats. However this should be addressed in future studies.

In northern Chile, studies dealing with the ecology of soft-bottom invertebrate's assemblages often report species taxonomic composition and/or trophic guilds usually from samples or experiments conducted at day hours (e.g., Laudien et al. 2007, Pacheco et al. 2010, 2012, 2013). Understanding of the dynamics of these assemblages could improve by not only asking what and how many species they are composed of (i.e., taxonomical diversity) but rather addressing questions about what these species do (i.e., functional diversity). In that sense, our study shows the importance of considering diel emergence of several invertebrate species which may help to explain the striking variation in space and time often found in benthic communities.

\section{ACKNOWLEDGMENTS}

We thank Patricia Ayón and Daniela Araya for helping us with copepods taxonomy. Espiridion Montanares, Guillermo Benavides, Pablo Santoro, Maritza Malebran and Cynthia Cortes are thanked for supporting field and laboratory work. Comments by two reviewers help us to improve and early version of this manuscript. This study was financed by FONDECYT N 11110030 research fund granted to A. S. Pacheco.

\section{LITERATURE CITED}

Akiyama T \& M Yamamoto. 2004. Life history of Nippoleucon hinumensis (Crustacea: Cumacea: Leuconidae) in Seto Inland Sea of Japan. I. Summer diapause and molt cycle. Marine Ecology Progress Series 284: 211-225.

Alldredge AL \& JM King. 1980. Effects of moonlight on the vertical migration patterns of demersal zooplankton. Journal of Experimental Marine Biology and Ecology. 44: 133-156.

Alldredge AL \& JM King. 1985. The distance demersal zooplankton migrates above the benthos: implications for predation. Marine Biology 84: 253-260. 
Armonies W. 1988. Physical factors influencing active emergence of meiofauna from boreal intertidal sediment. Marine Ecology Progress Series 49: 277-286.

Armonies W. 1994. Drifting meio- and macrobenthic invertebrates on tidal flats in Königshafen: a review. Helgoländer Meeresuntersuchungen 48: 299-320.

Jørgensen NM \& H Christie. 2003. Diurnal, horizontal and vertical dispersal of kelp-associated fauna. Hydrobiologia 503: 69-76.

Hicks GRF. 1988. Evolutionary implications of swimming behaviour in meiobenthic copepods. Hydrobiologia 167/ 168: 497-504.

Laudien J, M Rojo, M Oliva, W Arntz \& S Thatje. 2007. Sublittoral soft-bottom communities and diversity of Mejillones Bay in northern Chile (Humboldt Current upwelling system). Helgoland Marine Research 61: 103116.

Mees J \& MB Jones. 1997. The hyperbenthos. Oceanography and Marine Biology: An Annual Review 35: 221-255.

Pacheco AS, J Laudien, M Thiel, M Oliva \& W Arntz. 2010. Succession and seasonal variation in the development of subtidal macrobenthic soft-bottom communities off northern Chile. Journal of Sea Research 64: 180-189.

Pacheco AS, M Thiel, M Oliva \& JM Riascos. 2012. Effects of patch size and position above the substratum during early succession of subtidal soft-bottom communities. Helgoland Marine Research 66: 523-536.

Pacheco AS, RA Uribe, M Thiel, M Oliva \& JM Riascos. 2013. Dispersal of post-larval macrobenthos in subtidal sedimentary habitats: roles of vertical diel migration, water column, water column, bedload transport and biological trait's expression. Journal of Sea Research 77: 79-92.

Palmer MA. 1988. Dispersal of marine meiofauna: a review and conceptual model explaining passive transport and active emergence with implications for recruitment. Marine Ecology Progress Series 48: 81-91.
Teasdale M, K Vopel \& D Thistle. 2004. The timing of benthic copepod emergence. Limnology and Oceanography 49: 884889.

Thistle D. 2003. Harpacticoid copepod emergence at a shelf site in summer and winter: implications for hydrodynamic and mating hypotheses. Marine Ecology Progress Series 248: 177-185.

Thistle D, L Sedlacek, KR Carman, JW Fleeger \& JP Barry. 2007. Emergence in the deep sea: evidence from harpacticoid copepods. Deep Sea Research I 54: 1008-1014.

Ullberg J \& E Ólafsson. 2003. Free-living marine nematodes actively choose habitat when descending from the water column. Marine Ecology Progress Series 260: 141-149.

Vallet C \& JC Dauvin. 2001. Biomass changes and benthopelagic transfers throughout the benthic boundary layer in the English Channel. Journal of Plankton Research. 9: 903922.

Vargas CA \& HE González. 2004. Plankton community structure and carbon cycling in a coastal upwelling system. I. Bacteria, microprotozoans and phytoplankton in the diet of copepods and appendicularians. Marine Ecology Progress Series 34: 151-164.

Vargas CA, RA Martínez, LA Cuevas, MA Pavez, C Cartes, HE González, R Escribano \& G Daneri. 2007. The relative importance of microbial and classical food webs in a highly productive coastal upwelling area. Limnology and Oceanography 52: 1495-1510.

Vopel K \& D Thistle. 2011. Cues, not an endogenous rhythm, control the dusk peak in water-column entry by benthic copepods. Estuaries and Coast 34: 1194-1204.

Walters K. 1991. Influences of abundance, behavior, species composition, and ontogenetic stage on active emergence of meiobenthic copepods in subtropical habitats. Marine Biology 108: 207-215.

Walters K \& SS Bell. 1994. Significance of copepod emergence to benthic, pelagic, and phytal linkages in a subtidal seagrass bed. Marine Ecology Progress Series 108: 237-249.

Received 20 September 2012 and accepted 17 June 2013

Editor: Claudia Bustos 